Research Article

\title{
STABILITY ANALYSIS FOR YIELD OF ADVANCED POTATO GENOTYPES FOR COMMERCIAL CULTIVATION IN BANGLADESH
}

\author{
B.C. Kundu ${ }^{1}$, M.A. Kawochar ${ }^{1}$, S. Naznin ${ }^{1}$, N.U. Ahmed ${ }^{2}$, S.C. Halder ${ }^{3}$ \\ M. Mostofa ${ }^{1 *}$ and H.K.M. Delowar ${ }^{4}$ \\ ${ }^{1}$ Tuber Crops Research Centre, Bangladesh Agricultural Research Institute \\ Gazipur-1701, Bangladesh \\ ${ }^{2}$ Tuber Crops Research Sub Centre, Bangladesh Agricultural Research Institute \\ Munshiganj, Bangladesh \\ ${ }^{3}$ Department of Biotechnology, Bangladesh Agricultural Research Institute \\ Gazipur-1701, Bangladesh \\ ${ }^{4}$ Department of Environmental Science and Technology \\ Jashore University of Science and Technology, Jashore-7408, Bangladesh
}

\begin{abstract}
Five advanced potato genotypes, along with three check varieties were evaluated at six locations in order to find out the stable varieties for commercial cultivation in Bangladesh. Combined analysis exhibited a highly significant variability among the genotypes, locations and GEI. The average tuber yield at 90 days after planting (DAP) of the genotypes ranged from $31.18 \mathrm{t} \mathrm{ha}^{-1}$ in the check BARI Alu-28 to $43.8 \mathrm{t} \mathrm{ha}^{-1}$ in the clone 9.35. The result of $A M M I$ analysis of tuber yield at $90 \mathrm{DAP}$ also showed that the first IPCA1 captured $55.30 \%$ of the interaction SS. IPCA2, IPCA3 and IPCA4 explained $29.01,8.55$ and $7.08 \%$ of GE interaction SS, respectively. In general, the AMMI2 model contained $99.94 \%$ of the treatment SS, while the residual contained $0.06 \%$. In ASV method, the clone 9.125 , followed by the check BARI Alu-28 and clone 9.91 were more stable than 9.35. Biplot of IPCA1 and IPCA2 covers $84.3 \%$ of GE interaction. Biplot analysis also showed that clone 9.44 and 9.35 and the environment of Gazipur and Jashore had a better result in the GE interaction. Clone 9.44 had specific adaptation with the environment of Gazipur and Jashore, while 9.35 had specific adaptation with Gazipur and Jamalpur. Clone 9.125, 9.91, BARI Alu-28, BARI Alu-8 and clone 9.112 were located toward the center of the biplot and can be considered as stable. Based on the GSI the most desirable genotype for both stability and high tuber yield is the clone 9.125 followed by clones 9.112, 9.91 and 9.35 .
\end{abstract}

Keywords: AMMI analysis; GxE interactions; Potato genotypes; Stability; Tuber yield.

\footnotetext{
"Corresponding author: marufsau@ @otmail.com
} 
Kundu et al.

\section{INTRODUCTION}

Potato (Solanum tuberosum L.) is the $4^{\text {th }}$ largest food crop of the world and $2^{\text {nd }}$ crop in Bangladesh. It is a high biological value crop that gives high yield with good nutrition per unit area and time than any other major crop. Thus, it can play a vital role in the human diet as a supplement to other food crops such as wheat and rice (Badoni and Chauhan, 2010). In Bangladesh, it is still used as a crucial vegetable. Bangladesh produced about 9.6 million tons of potato from about 0.468 million hectares of land, with an average yield of $20.61 \mathrm{t} \mathrm{ha}^{-1}$ during the fiscal year 2018-19 (BBS, 2019). But the on-station tuber yield is higher than that of farmers' fields. One of the considerable factors contributing to low yield is the insufficiency of improved cultivars with wide adaptability. Thus, the evaluations of genotypes across different environments are essential for the selection of varieties.

Evaluating genotypes over diverse environments area universal practice to ensure the stability of the performance of the genotypes (Sadeghi et al., 2011). One of the most desirable properties of a genotype is stability in performance before releasing as a variety for wide cultivation (Singh and Chaudhary, 1977). One of the major stability measures is the static stability concept (Becker and Leon, 1988). High yield stability usually refers to a genotype's ability to perform consistently across a wide range of environments. Genotypes are selected primarily on the basis of the mean performances across environments for that crop year, may not be the most stable (Yau and Hamblin, 1994). However, the activity of identification, selection and recommendation of superior genotypes is complicated and severely limited by genotype $\times$ environment interactions that are inevitable in multi-environmental trials (Asfaw et al., 2009). The presence of genotype $\mathrm{x}$ environment interaction may confound the genotypic performance with environmental effects (Thillainathan and Fernandez, 2002).

A combined analysis of variance (ANOVA) can quantify the interactions and describe the main effects. Several statistical techniques are used to decrease the effect of the $G \times E$ interaction. Recently, the quantification of $\mathrm{G} \times \mathrm{E}$ interactions and yield stability studies has been done through multivariate methods, such as principal component analysis (Rea et al., 2011). The additive main effect and multiplicative interaction (AMMI) method combines analysis of variance (ANOVA) and principal component analysis (PCA) into a unified approach that can be used to analyze multi-location trials (Gauch and Zobel, 1996). To increase accuracy, additive main effects and multiplicative interaction (AMMI) are the models of the first choice when main effects and interaction are both important (Zobel et al., 1988). The objective of this study was to identify high yielding varieties with stable performance across different environments.

\section{MATERIALS AND METHODS}

Five clonal hybrids developed by TCRC (Tuber Crops Research Centre), BARI (Bangladesh Agricultural Research Institute), were evaluated along with BARI Alu-7 
(Diamant), BARI Alu-8 (Cardinal) and BARI Alu-28 (Lady Rosetta) as checks following RCB design with three replications at six locations (Bogura, Debigonj, Gazipur, Jamalpur, Jashore, and Munshigonj). The unit plot size was $3 \mathrm{~m} \times 3 \mathrm{~m}$. Whole tubers were planted at $60 \mathrm{~cm} \times 25 \mathrm{~cm}$ spacing. Planting was done in the second half of November 2013. Fertilizer doses and necessary intercultural operations were done as per TCRC recommendation (Kundu et al., 2018). The crop was harvested at 90 DAP (days after planting).

Data were recorded on several parameters and subjected to combined analysis using MSTAT-C. Treatment means were separated by DMRT.

As described by Zobel et al. (1988), the phenotypic stability parameters were estimated using the AMMI model as follows:

$$
\mathrm{Y}_{\mathrm{ij}}=\mu+\mathrm{g}_{\mathrm{i}}+\mathrm{e}_{\mathrm{j}}+\sum_{k=1}^{n} \lambda_{\mathrm{k}} \alpha_{\mathrm{ik}} \mathrm{y}_{\mathrm{jk}}+\mathrm{r}_{\mathrm{ij}}+\varepsilon_{\mathrm{ij}}
$$

Where, $Y_{i j}$ is the mean response of genotype $\mathrm{i}$ in the environment $\mathrm{j}$;

$\mu$ is the overall mean;

$\mathrm{g}_{\mathrm{i}}$ is the fixed effect of genotype $\mathrm{i}(\mathrm{i}=1,2, \ldots \mathrm{g})$;

$e_{j}$ is the random effect of environment $j(j=1,2, \ldots e)$;

$\lambda_{\mathrm{k}}$ is a unique value of the $\mathrm{k}^{\text {th }}$ interaction principal component analysis (IPCA), $(\mathrm{k}=1,2, \mathrm{p}$, where $\mathrm{p}$ is the maximum number of estimable main components),

$\alpha_{\mathrm{ik}}$ is a singular value for the $\mathrm{i}^{\text {th }}$ genotype in the $\mathrm{k}^{\text {th }}$ IPCA,

$\mathrm{y}_{\mathrm{jk}}$ is a unique value of the $\mathrm{j}^{\text {th }}$ environment in the $\mathrm{k}^{\text {th }}$ IPCA;

$\mathrm{r}_{\mathrm{ij}}$ is the error for the $\mathrm{G} \times \mathrm{E}$ interaction or AMMI residue (noise present in the data); and $\mathrm{k}$ is the characteristic non-zero roots, $\mathrm{k}=[1,2, \ldots \min (\mathrm{G}-1, \mathrm{E}-1)]$.

$\varepsilon_{\mathrm{ij}}$ is the average experimental error; the $\mathrm{G} \times \mathrm{E}$ interaction is represented by the factors;

The sum of squares for the $\mathrm{G} \times \mathrm{E}$ interaction $(\mathrm{SSG} \times \mathrm{E}$ ) was divided into $n$ singular axes or main components of interaction (IPCA), which described the standard portion, each axis corresponding to an AMMI model. The choice of a model that best described the $\mathrm{G} \times \mathrm{E}$ interaction was done based on the $\mathrm{F}_{\mathrm{R}}$ test proposed by Cornelius et al. (1992).

The predictive averages were estimated according to the selected model. The CROPSTAT software was used for AMMI analysis.

As described by Purchase et al. (2000), AMMI stability value (ASV) was calculated as:

$$
\mathbf{A S V}=\sqrt{\left[\frac{I P C A 1_{\text {sum of squre }}}{\left[\text { IPCA2 } 2_{\text {sum of squre }}\right.}\left(\text { IPCA } 1_{\text {score }}\right)\right]^{2}+\left(I P C A 2_{\text {score }}\right)^{2}}
$$


Where, $\frac{S S_{I P C A 1}}{S S_{I P C A 2}}$ is the weight given to the IPCA1-value by dividing the IPCA1 sum of squares by the IPCA2 sum of squares. The larger the IPCA score, either negative or positive, the more specifically adapted a genotype is to certain environments. Smaller ASV scores indicate a more stable genotype across environments.

\section{Genotype Selection Index:}

Based on the rank of mean grain yield of genotypes $\left(\mathrm{RY}_{\mathrm{i}}\right)$ across environments and rank of AMMI stability value (RASV ${ }_{\mathrm{i}}$ ) a selection index called GSI was calculated for each genotype (Farshadfar, 2008) which incorporates both mean grain yield and stability index in a single criterion $\left(\mathrm{GSI}_{\mathrm{i}}\right)$ as:

$$
\mathrm{GSI}_{\mathrm{i}}=\mathrm{RASV}_{\mathrm{i}}+\mathrm{RY}_{\mathrm{i}}
$$

\section{RESULTS AND DISCUSSION}

The result of the combined analysis of data showed that the genotypes, locations and their interactions were statistically significant for different traits (Table 1). The effect of locations presented in Table 2 revealed that traits were significantly influenced by locations. Emergence \% at 30 DAP was significantly higher in Debigonj, Gazipur, Jamalpur and Jashore and was minimum in Bogura. The tallest plant was found in Munshigonj and Debigonj and the lowest was in Gazipur. The highest number of stems/hill and tuber yield $\left(\mathrm{t} \mathrm{ha}^{-1}\right)$ were found in Jamalpur. The tuber number/hill, tuber weight $(\mathrm{kg}) / \mathrm{hill}$, single tuber weight, tuber number/stem and tuber yield $\left(\mathrm{t} \mathrm{ha}{ }^{-1}\right)$ were the best at Debigonj. It can be said that Debigonj is the best place for commercial table potato cultivation. However, the high dry matter was found in Gazipur (Table 2).

Table 1. Combined analysis of variance of different characters at six locations

\begin{tabular}{lcccccc}
\hline \multirow{2}{*}{$\begin{array}{l}\text { Source of } \\
\text { variation }\end{array}$} & df & \multicolumn{5}{c}{ MSS } \\
\cline { 3 - 7 } & $\begin{array}{c}\text { Emergence } \\
\text { \% at 30 DAP }\end{array}$ & $\begin{array}{c}\text { Plant height } \\
(\mathrm{cm})\end{array}$ & $\begin{array}{c}\text { No. of } \\
\text { stem/hill }\end{array}$ & $\begin{array}{c}\text { Foliage } \\
\text { coverage }(\%)\end{array}$ & Plant vigor \\
\hline Location & 5 & $256.138^{*}$ & $2036.814^{* *}$ & $26.608^{* *}$ & $1221.828^{* *}$ & $26.524^{* *}$ \\
Error-I & 12 & 47.766 & 72.648 & 0.796 & 28.090 & 0.757 \\
Genotypes & 7 & $71.764^{* *}$ & $976.165^{* *}$ & $7.761^{* *}$ & $97.313^{* *}$ & $3.821^{* *}$ \\
LxG & 35 & $19.146^{*}$ & $87.409^{* *}$ & $2.587 * *$ & $18.542^{* *}$ & $1.346^{* *}$ \\
Error-II & 84 & 17.100 & 22.960 & 0.486 & 18.186 & 0.404 \\
Location & 5 & $207.425^{* *}$ & $0.090^{* *}$ & $375.957^{* *}$ & $26.574^{* *}$ & $1248.723^{* *}$ \\
Error-I & 12 & 1.396 & 0.004 & 12.487 & 0.474 & 40.375 \\
Genotypes & 7 & $37.429^{* *}$ & $0.082^{* *}$ & $358.809^{* *}$ & $11.201^{* *}$ & $404.652^{* *}$ \\
LxG & 35 & $8.621^{* *}$ & $0.009^{*}$ & $31.549^{* *}$ & $3.674^{* *}$ & $97.936^{* *}$ \\
Error-II & 84 & 1.035 & 0.005 & 8.438 & 0.607 & 18.453 \\
\hline
\end{tabular}

*Significant at $5 \%$ level of probability and **Significant at $1 \%$ level of probability 
Table 2. Mean performances of the genotypes over locations for different characters

\begin{tabular}{|c|c|c|c|c|c|}
\hline Location & $\begin{array}{c}\text { Emergence } \\
\% \text { at } 30 \\
\text { DAP }\end{array}$ & $\begin{array}{c}\text { Plant } \\
\text { height }(\mathrm{cm})\end{array}$ & $\begin{array}{l}\text { No. of stem } \\
\text { /hill }\end{array}$ & $\begin{array}{c}\text { Foliage } \\
\text { coverage } \\
(\%)\end{array}$ & Plant vigor \\
\hline Bogura & $90.90 \mathrm{~b}$ & $56.82 \mathrm{~b}$ & $6.93 \mathrm{a}$ & 87.54 b & $8.458 \mathrm{~b}$ \\
\hline Debigonj & $97.36 \mathrm{a}$ & $75.10 \mathrm{a}$ & $6.51 \mathrm{a}$ & $93.83 \mathrm{a}$ & $6.583 \mathrm{~d}$ \\
\hline Gazipur & $97.36 \mathrm{a}$ & $59.26 \mathrm{~b}$ & $5.24 \mathrm{~b}$ & $87.29 \mathrm{~b}$ & $8.479 \mathrm{~b}$ \\
\hline Jamalpur & $97.15 \mathrm{a}$ & $59.43 \mathrm{~b}$ & $7.10 \mathrm{a}$ & $78.13 \mathrm{c}$ & $7.250 \mathrm{c}$ \\
\hline Jashore & $97.15 \mathrm{a}$ & $59.43 \mathrm{~b}$ & $7.10 \mathrm{a}$ & $78.13 \mathrm{c}$ & $7.250 \mathrm{c}$ \\
\hline Munshigonj & 90.96 b & $77.70 \mathrm{a}$ & $4.65 \mathrm{c}$ & $94.17 \mathrm{a}$ & $9.417 \mathrm{a}$ \\
\hline$S_{E}$ & 1.409 & 1.74 & 0.182 & 1.082 & 0.178 \\
\hline $\mathrm{CV}(\%)$ & 4.35 & 7.41 & 11.15 & 4.93 & 8.04 \\
\hline Bogura & $12.55 \mathrm{~b}$ & $0.516 \mathrm{c}$ & $34.46 \mathrm{c}$ & $19.00 \mathrm{c}$ & $86.57 \mathrm{bc}$ \\
\hline Debigonj & $15.04 \mathrm{a}$ & $0.636 \mathrm{a}$ & $42.47 \mathrm{a}$ & $19.46 \mathrm{~b}$ & $89.73 \mathrm{~b}$ \\
\hline Gazipur & $7.824 \mathrm{~d}$ & $0.520 \mathrm{c}$ & $34.69 \mathrm{c}$ & $20.79 \mathrm{a}$ & $76.52 \mathrm{~d}$ \\
\hline Jamalpur & $8.692 \mathrm{c}$ & $0.594 \mathrm{~b}$ & $39.60 \mathrm{~b}$ & $19.82 \mathrm{~b}$ & $94.93 \mathrm{a}$ \\
\hline Jashore & $8.616 \mathrm{c}$ & $0.613 \mathrm{ab}$ & $40.05 \mathrm{~b}$ & $19.82 \mathrm{~b}$ & $94.94 \mathrm{a}$ \\
\hline Munshigonj & $8.236 \mathrm{~cd}$ & $0.485 \mathrm{c}$ & $32.42 \mathrm{c}$ & $17.64 \mathrm{~d}$ & $82.67 \mathrm{c}$ \\
\hline$S_{E}$ & 0.241 & 0.013 & 0.721 & 0.141 & 1.297 \\
\hline $\mathrm{CV}(\%)$ & 10.01 & 12.17 & 7.79 & 4.01 & 9.91 \\
\hline
\end{tabular}

The mean foliar and tuber characteristics are presented in Table 3, which indicates that the emergence, no of stems per hill and plant vigor were more or less similar to the check varieties. The clones 9.125, 9.44 and 9.91 plants are tall. Foliage coverage was the best in the clone 9.35 , but all others were similar. The no of tubers was the highest (12.73/hill) in the same clone. Tuber yield per hill also was the highest in this clone, but all the clones produced better yields compared to the checks. The proportion of seed-sized tuber was very high in all the clones except the clone 9.35 (76.5\%), indicating the tuber size of this clone is bigger than the others. 
Table 3. Mean performances of the genotypes over six locations

\begin{tabular}{lcccccccc}
\hline Genotypes & $\begin{array}{c}\text { Emergence } \\
\text { \% at 30 DAP }\end{array}$ & $\begin{array}{c}\text { Plant } \\
\text { height } \\
(\mathrm{cm})\end{array}$ & $\begin{array}{c}\text { Number } \\
\text { of stems } \\
\text { /hills }\end{array}$ & $\begin{array}{c}\text { Foliage } \\
\text { coverage } \\
(\%)\end{array}$ & $\begin{array}{c}\text { Plant } \\
\text { vigor }(1- \\
10 \mathrm{score})\end{array}$ & $\begin{array}{c}\text { Tuber } \\
\text { number/ } \\
\text { hill }\end{array}$ & $\begin{array}{c}\text { Tuber } \\
\text { weight / } / \\
\text { hill (kg) }\end{array}$ & $\begin{array}{c}\text { Seed } \\
\text { tuber } \\
\text { sized by } \\
\text { wt. }(\%)\end{array}$ \\
\hline 9.112 & $96.76 \mathrm{ab}$ & $56.90 \mathrm{e}$ & $6.57 \mathrm{~b}$ & $88.11 \mathrm{~b}$ & $8.64 \mathrm{a}$ & $11.77 \mathrm{~b}$ & $0.64 \mathrm{ab}$ & $86.57 \mathrm{c}$ \\
9.125 & $95.65 \mathrm{ab}$ & $72.26 \mathrm{ab}$ & $5.27 \mathrm{~d}$ & $85.83 \mathrm{bcd}$ & $7.81 \mathrm{bc}$ & $8.276 \mathrm{f}$ & $0.59 \mathrm{bc}$ & $89.73 \mathrm{~b}$ \\
9.35 & $95.46 \mathrm{ab}$ & $65.63 \mathrm{c}$ & $7.31 \mathrm{a}$ & $91.00 \mathrm{a}$ & $8.33 \mathrm{a}$ & $12.73 \mathrm{a}$ & $0.66 \mathrm{a}$ & $76.52 \mathrm{e}$ \\
9.44 & $90.83 \mathrm{c}$ & $74.58 \mathrm{a}$ & $5.48 \mathrm{~d}$ & $86.67 \mathrm{bcd}$ & $7.86 \mathrm{bc}$ & $9.232 \mathrm{e}$ & $0.56 \mathrm{c}$ & $94.93 \mathrm{a}$ \\
9.91 & $94.16 \mathrm{~b}$ & $71.11 \mathrm{~b}$ & $6.40 \mathrm{bc}$ & $87.17 \mathrm{bc}$ & $8.22 \mathrm{ab}$ & $10.29 \mathrm{c}$ & $0.55 \mathrm{c}$ & $94.94 \mathrm{a}$ \\
Cardinal & $95.27 \mathrm{ab}$ & $62.40 \mathrm{~d}$ & $6.57 \mathrm{~b}$ & $85.33 \mathrm{bcd}$ & $7.64 \mathrm{~cd}$ & $9.403 \mathrm{de}$ & $0.54 \mathrm{c}$ & $82.67 \mathrm{~d}$ \\
Diamant & $95.64 \mathrm{ab}$ & $56.86 \mathrm{e}$ & $6.46 \mathrm{~b}$ & $83.67 \mathrm{~d}$ & $7.47 \mathrm{~cd}$ & $9.586 \mathrm{cde}$ & $0.48 \mathrm{~d}$ & $92.97 \mathrm{f}$ \\
L. Rosetta & $97.41 \mathrm{a}$ & $57.26 \mathrm{e}$ & $5.97 \mathrm{c}$ & $84.33 \mathrm{~cd}$ & $7.28 \mathrm{~d}$ & $9.988 \mathrm{~cd}$ & $0.47 \mathrm{~d}$ & $79.12 \mathrm{e}$ \\
$\mathrm{S}_{\mathrm{E}}$ & 0.975 & 1.129 & 0.164 & 1.005 & 0.150 & 0.240 & 0.017 & 1.013 \\
\hline
\end{tabular}

The yield of all genotypes in all the locations is presented in Table 4. On an average the clone 9.35 gave the highest yield $\left(43.78 \mathrm{t} \mathrm{ha}^{-1}\right)$ followed by clone $9.112(41.81 \mathrm{t}$ $\left.\mathrm{ha}^{-1}\right), 9.125\left(39.44 \mathrm{t} \mathrm{ha}^{-1}\right), 9.44\left(38.10 \mathrm{t} \mathrm{ha}^{-1}\right)$ and $9.91\left(37.21 \mathrm{t} \mathrm{ha}^{-1}\right)$, the lowest tuber yield (32.02 and $31.18 \mathrm{t} \mathrm{ha}^{-1}$, successively) were given by the check BARI Alu-7 (Diamant) and BARI Alu-28 (Lady Rosetta). The clone 9.35 gave a better yield than the check in all the locations, and the highest yield in four of the six locations. So, on the basis of yield, all the clones can be selected for commercial purposes of the other required traits and found good.

Table 4. Tuber yields $\left(\mathrm{t} \mathrm{ha}^{-1}\right)$ of all the varieties at six locations (90 DAP)

\begin{tabular}{|c|c|c|c|c|c|c|c|}
\hline \multirow{2}{*}{ Genotypes } & \multicolumn{7}{|c|}{ Location } \\
\hline & Bogura & Debigonj & Gazipur & Jamalpur & Jashore & Munshigonj & Mean \\
\hline 9.112 & $38.62 \mathrm{e}-\mathrm{j}$ & $49.00 \mathrm{ab}$ & $37.57 \mathrm{e}-\mathrm{k}$ & $41.92 \mathrm{c}-\mathrm{g}$ & $47.30 \mathrm{abc}$ & 36.42 g-n & $41.81 \mathrm{~b}$ \\
\hline 9.125 & 37.80 e-k & $45.15 \mathrm{bcd}$ & $37.73 \mathrm{e}-\mathrm{k}$ & 38.58 e-j & $42.22 \mathrm{c}-\mathrm{f}$ & $35.16 \mathrm{i}-\mathrm{n}$ & $39.44 \mathrm{c}$ \\
\hline 9.35 & $41.42 \mathrm{~d}-\mathrm{h}$ & $52.12 \mathrm{a}$ & $45.51 \mathrm{bcd}$ & $51.54 \mathrm{a}$ & $37.42 \mathrm{e}-1$ & $34.65 \mathrm{i}-\mathrm{n}$ & $43.78 \mathrm{a}$ \\
\hline 9.44 & $31.671-\mathrm{p}$ & $42.63 \mathrm{c}-\mathrm{f}$ & $39.96 \mathrm{~d}-\mathrm{i}$ & $37.42 \mathrm{e}-1$ & $45.44 \mathrm{bcd}$ & $31.48 \mathrm{~m}-\mathrm{p}$ & $38.10 \mathrm{~cd}$ \\
\hline 9.91 & 32.68 k-p & $42.91 \mathrm{cde}$ & $34.43 \mathrm{i}-\mathrm{n}$ & $42.22 \mathrm{c}-\mathrm{f}$ & $40.21 \mathrm{~d}-\mathrm{i}$ & 30.81 nop & $37.21 \mathrm{~d}$ \\
\hline Cardinal & $33.41 \mathrm{j}-\mathrm{o}$ & $37.10 \mathrm{f}-\mathrm{m}$ & $31.681-\mathrm{p}$ & 35.95 h-n & 37.28 e-m & $32.81 \mathrm{j}-\mathrm{p}$ & $34.70 \mathrm{e}$ \\
\hline Diamant & $32.08 \mathrm{kl}-\mathrm{p}$ & $37.13 \mathrm{f}-\mathrm{m}$ & $23.26 \mathrm{q}$ & 33.48 j-o & $35.39 \mathrm{i}-\mathrm{n}$ & 30.76 nop & $32.02 \mathrm{f}$ \\
\hline L.Rosetta & 27.9 opq & $33.69 \mathrm{j}-\mathrm{n}$ & $27.37 \mathrm{pq}$ & $35.65 \mathrm{i}-\mathrm{n}$ & $35.18 \mathrm{i}-\mathrm{n}$ & $27.24 \mathrm{pq}$ & $31.18 \mathrm{f}$ \\
\hline$S_{E}$ & \multicolumn{6}{|c|}{1.677} & 0.6847 \\
\hline
\end{tabular}

Dry matter content (21.93\%) was the highest in the check variety BARI Alu-28 (Lady Rosetta) at Jamalpur and Jashore which was similar to that of the same variety 
at Bogura (21.0\%), Debigonj (20.85\%) and Gazipur (20.46\%), and clone 9.91 at Debigonj (21.30\%) and Gazipur (21.01\%) (Table 5). Considering the average all the varieties were somewhat similar but none of the clones were better than the checks, which indicated that none of the clones is suitable for processing. Tuber grades also showed that all the clones are suitable for table purpose (Table 6).

Table 5. Dry matter content of all the varieties at six locations

\begin{tabular}{lccccccc}
\hline \multirow{2}{*}{ Genotypes } & \multicolumn{7}{c}{ Dry matter at 90 DAP (\%) } \\
\cline { 2 - 8 } & Bogura & Debigonj & Gazipur & Jamalpur & Jashore & Munshigonj & Mean \\
\hline 9.112 & $18.33 \mathrm{j}-\mathrm{m}$ & $17.191 \mathrm{mn}$ & $20.83 \mathrm{a}-\mathrm{e}$ & $20.26 \mathrm{~b}-\mathrm{g}$ & $19.56 \mathrm{c}-\mathrm{j}$ & $19.12 \mathrm{~g}-\mathrm{j}$ & $19.21 \mathrm{~cd}$ \\
9.125 & $17.33 \mathrm{k}-\mathrm{n}$ & $18.55 \mathrm{i}-\mathrm{l}$ & $21.2 \mathrm{ab}$ & $16.82 \mathrm{n}$ & $19.51 \mathrm{~d}-\mathrm{j}$ & $17.02 \mathrm{mn}$ & $18.41 \mathrm{e}$ \\
9.35 & $18.33 \mathrm{j}-\mathrm{m}$ & $18.34 \mathrm{j}-\mathrm{m}$ & $20.06 \mathrm{~b}-\mathrm{i}$ & $19.56 \mathrm{c}-\mathrm{j}$ & $19.92 \mathrm{~b}-\mathrm{i}$ & $16.57 \mathrm{n}$ & $18.80 \mathrm{de}$ \\
9.44 & $18.67 \mathrm{~h}-\mathrm{k}$ & $20.18 \mathrm{~b}-\mathrm{h}$ & $20.74 \mathrm{a}-\mathrm{f}$ & $19.92 \mathrm{~b}-\mathrm{i}$ & $20.26 \mathrm{~b}-\mathrm{g}$ & $16.30 \mathrm{n}$ & $19.34 \mathrm{~cd}$ \\
9.91 & $19.33 \mathrm{e}-\mathrm{j}$ & $21.30 \mathrm{ab}$ & $21.01 \mathrm{a}-\mathrm{d}$ & $19.51 \mathrm{~d}-\mathrm{j}$ & $16.82 \mathrm{n}$ & $16.39 \mathrm{n}$ & $19.06 \mathrm{~cd}$ \\
Cardinal & $20.00 \mathrm{~b}-\mathrm{i}$ & $20.26 \mathrm{~b}-\mathrm{g}$ & $20.79 \mathrm{a}-\mathrm{e}$ & $21.09 \mathrm{abc}$ & $21.09 \mathrm{abc}$ & $16.92 \mathrm{mn}$ & $20.03 \mathrm{~b}$ \\
Diamant & $19.00 \mathrm{~g}-\mathrm{j}$ & $19.03 \mathrm{~g}-\mathrm{j}$ & $21.21 \mathrm{ab}$ & $19.46 \mathrm{~d}-\mathrm{j}$ & $19.46 \mathrm{~d}-\mathrm{j}$ & $19.23 \mathrm{f}-\mathrm{j}$ & $19.57 \mathrm{bc}$ \\
L.Rosetta & $21.00 \mathrm{a}-\mathrm{d}$ & $20.85 \mathrm{a}-\mathrm{e}$ & $20.46 \mathrm{a}-\mathrm{g}$ & $21.93 \mathrm{a}$ & $21.93 \mathrm{a}$ & $19.59 \mathrm{c}-\mathrm{j}$ & $20.96 \mathrm{a}$ \\
S $_{\mathrm{E}}$ & & & 0.4498 & & & 0.1836 \\
\hline
\end{tabular}

Table 6. Tuber grades of the genotypes (Average of six locations) by number and weight

\begin{tabular}{lcccccc}
\hline \multirow{2}{*}{ Genotypes } & \multicolumn{3}{c}{ Grading by number $(\%)$} & \multicolumn{3}{c}{ Grading by weight (\%) } \\
\cline { 2 - 7 } & $<28 \mathrm{~mm}$ & $28-55 \mathrm{~mm}$ & $>55 \mathrm{~mm}$ & $<28 \mathrm{~mm}$ & $28-55$ & $>55$ \\
\hline 9.112 & 15.67 & 82.97 & 1.37 & 2.54 & 93.07 & 4.39 \\
9.125 & 13.66 & 79.28 & 7.06 & 1.68 & 79.12 & 19.20 \\
9.35 & 19.26 & 77.68 & 3.06 & 3.92 & 85.93 & 10.15 \\
9.44 & 17.16 & 78.65 & 4.19 & 2.99 & 84.44 & 12.57 \\
9.91 & 19.24 & 78.35 & 2.42 & 3.64 & 87.65 & 8.72 \\
Cardinal & 16.54 & 81.19 & 2.27 & 3.63 & 88.73 & 7.64 \\
Diamant & 18.45 & 79.13 & 2.42 & 4.11 & 87.52 & 8.38 \\
L.Rosetta & 11.49 & 87.35 & 1.16 & 1.95 & 94.07 & 3.98 \\
\hline
\end{tabular}

\section{Yield adaptation across the environments}

Combined analysis of variance (Table 7) over locations resulted in highly significant differences $(\mathrm{P}<0.01)$ in the interaction of genotypes $\times$ environments (locations). Chandra et al. (1971) reported that GE interaction with location is more important than GE interaction with year. The significant interactions of genotypes $\times$ 
environments suggest that tuber yield of genotypes at 90 DAP varied across environments. Significant differences for genotypes, environments and GE interaction indicated the effect of environments in the GE interaction, genetic variability among the entries and possibility of selection for stable genotypes. Therefore, we can further proceed and estimate phenotypic stability as GE interaction was significant (Farshadfar and Sutka, 2003; Farshadfar and Sutka, 2006).

Table 7. Combined additive, multiplicative interaction and analysis of variance for tuber yield at 90 DAP of 8 potato genotypes grown at six locations

\begin{tabular}{lccc}
\hline \multicolumn{1}{c}{ Source of variance } & D.F. & MSS & TSS\% \\
\hline Genotype & 7 & $119.623^{* *}$ & \\
Environment & 5 & $125.341^{* *}$ & \\
G x E & 35 & $10.5144^{* *}$ & \\
$\quad$ IPCA 1 & 11 & $18.4994^{*}$ & 55.30 \\
IPCA 2 & 9 & $11.8617^{*}$ & 29.01 \\
IPCA 3 & 7 & 4.49690 & 8.55 \\
IPCA 4 & 5 & $5.21070^{* *}$ & 7.08 \\
GXE Residual & 3 & 0.074483 & 0.06 \\
Total & 47 & - & - \\
Pool error & 96 & - & - \\
\hline
\end{tabular}

*Significant at $5 \%$ level of probability and **Significant at $1 \%$ level of probability

The average tuber yield at 90 DAP of the genotypes ranged from 31.18 tha $^{-1}$ in check BARI Alu-28 (Lady Rosetta) to $43.8 \mathrm{t} \mathrm{ha}^{-1}$ in clone 9.35 (Table 8). The rank of genotypes based on AMMI predicted yield and observed means for tuber yield at 90 DAP of eight genotypes grown in six locations are presented in Table 9.

Table 8. AMMI predicted tuber yields $\left(\mathrm{t} \mathrm{ha}^{-1}\right)$ at 90 DAP of 8 genotypes grown at six locations

\begin{tabular}{cccccccc}
\hline Genotypes & Bogura & Debigon & Gazipur & Jamalpur & Jashore & Munshigonj & Mean \\
\hline 9.112 & 39.1 & 47.14 & 39.02 & 41.46 & 46.5 & 37.62 & 41.81 \\
9.125 & 37.47 & 45.91 & 37.19 & 38.74 & 42.47 & 34.84 & 39.44 \\
9.35 & 41.41 & 52.19 & 45.45 & 51.56 & 37.45 & 34.6 & 43.78 \\
9.44 & 31.65 & 42.94 & 39.68 & 37.51 & 45.61 & 31.19 & 38.1 \\
9.91 & 33.17 & 41.6 & 35.38 & 41.93 & 39.74 & 31.44 & 37.21 \\
Cardinal & 32.83 & 39.3 & 29.98 & 36.49 & 38.22 & 31.4 & 34.7 \\
Diamant & 32.4 & 36.34 & 23.82 & 33.3 & 35.12 & 31.1 & 32.02 \\
L. Rosetta & 27.61 & 34.3 & 26.97 & 35.77 & 35.32 & 27.13 & 31.18 \\
Site means & 34.46 & 42.47 & 34.69 & 39.59 & 40.05 & 32.41 & 37.28 \\
\hline
\end{tabular}


Table 9. Rank of genotypes based on AMMI predicted yield and observed means (in parenthesis) for tuber yield at 90 DAP of 8 genotypes grown in six locations

\begin{tabular}{lcccccc}
\hline Genotypes & Bogura & Debigonj & Gazipur & Jamalpur & Jashore & Munshigonj \\
\hline 9.112 & $17(16)$ & $3(3)$ & $18(20)$ & $12(12)$ & $4(4)$ & $21(26)$ \\
9.125 & $23(18)$ & $5(7)$ & $25(19)$ & $19(17)$ & $9(11)$ & $32(31)$ \\
9.35 & $13(13)$ & $1(1)$ & $7(5)$ & $2(2)$ & $24(22)$ & $33(32)$ \\
9.44 & $39(41)$ & $8(9)$ & $15(15)$ & $22(21)$ & $6(6)$ & $42(42)$ \\
9.91 & $36(38)$ & $11(8)$ & $29(33)$ & $10(10)$ & $14(14)$ & $40(43)$ \\
Cardinal & $37(36)$ & $16(25)$ & $44(40)$ & $26(27)$ & $20(23)$ & $41(37)$ \\
Diamant & $38(39)$ & $27(24)$ & $48(48)$ & $35(35)$ & $31(29)$ & $43(44)$ \\
L. Rosetta & $45(45)$ & $34(34)$ & $47(46)$ & $28(28)$ & $30(30)$ & $46(47)$ \\
\hline
\end{tabular}

\section{AMMI model and pattern analysis}

In the AMMI model, principal component analysis is based on the matrix of deviation from additivity or residual, while pattern analysis employs both classification and ordination techniques. In this respect, both the results of AMMI analysis, the genotype and the environment will be grouped based on their similar responses (Pourdad and Mohammadi, 2008).

Using ANOVA yield sum of square was partitioned into genotype, environment and GE interaction. GE interaction was further partitioned by principal component analysis (Table 10). The result of AMMI analysis also showed that the first interaction principal component axis (IPCA1) captured 55.30 of the interaction SS, IPCA2, IPCA3 and IPCA4 explained 29.01, 8.55 and $7.08 \%$ of GE interaction SS, respectively. The mean square for IPCA1 and IPCA2 were significant $(\mathrm{p}<5 \%)$ and cumulative accounted for $84.31 \%$ of total GE interaction. Therefore, the post-dictate evaluation using an F-test at $\mathrm{P}=5 \%$ suggests that two IPCA1 and IPCA2 were significant for the model with $20 \mathrm{df}$. In general, AMMI2 model contained $99.94 \%$ of the treatment SS, while the residual contained $0.06 \%$. These results indicate that the AMMI model fits the data well and justifies the use of AMMI2. 
Table 10. First, second, third IPCA scores, AMMI stability values (ASV), genotypic selection index (GSI) and rank for tuber yield at 90 DAP of 8 genotypes (mean of six locations)

\begin{tabular}{ccccccccc}
\hline Genotypes & Mean & IPCA1 & IPCA2 & IPCA3 & IPCA4 & ASVi & Rank & GSIi \\
\hline 9.112 & 41.81 & 0.739749 & 0.344189 & 0.632290 & -1.257020 & 1.08 & 5 & 7 \\
9.125 & 39.44 & 0.333320 & 0.203258 & 1.314450 & 0.475565 & 0.50 & 1 & 4 \\
9.35 & 43.78 & -3.327110 & -0.384151 & 0.359465 & 0.046747 & 4.61 & 8 & 9 \\
9.44 & 38.10 & 0.533681 & 2.444370 & -0.048793 & 0.233199 & 2.55 & 7 & 11 \\
9.91 & 37.21 & -0.468491 & 0.191527 & -1.019380 & -0.830650 & 0.67 & 3 & 8 \\
Cardinal & 34.70 & 0.616900 & -0.593437 & -0.018680 & 1.478990 & 1.04 & 4 & 10 \\
Diamant & 32.02 & 1.242450 & -1.886600 & 0.275898 & -0.493696 & 2.55 & 6 & 13 \\
L. Rosetta & 31.18 & 0.329501 & -0.319156 & -1.495250 & 0.346861 & 0.56 & 2 & 10 \\
\hline
\end{tabular}

\section{IPCAs crossover and non-cross over interaction}

IPCA scores of genotypes and environments displayed positive and negative values (Table 10 and 11). A genotype with a large positive IPCA score in some environments must have large negative interactions in some other environments. Thus, these scores presented a disproportionate genotype response (Yan and Hunt, 2001), which was the major source of variation for any crossover (qualitative) interaction. This disproportionate genotype response is referred to as crossover GE interaction for convenience. Diversely, scores with the same sign or near zero represent a non-crossover (quantitative) GE interaction or a proportionate genotype response (Farshadfar, 2008; Mohammadi and Amri, 2008).

Table 11. First, second, third IPCA scores, AMMI stability values (ASV) of six locations for tuber yield at 90 DAP

\begin{tabular}{lcccccc}
\hline \multicolumn{1}{c}{ Locations } & Mean & IPCA1 & IPCA2 & IPCA3 & IPCA4 & ASVi \\
\hline Bogura & 34.46 & 0.127910 & -1.492190 & 0.849334 & 0.455487 & 2 \\
Debigon & 42.47 & -0.850205 & 0.069392 & 1.184130 & -1.513630 & 1 \\
Gazipur & 34.69 & -1.484130 & 2.039860 & 0.318982 & 1.147270 & 5 \\
Jamalpur & 39.59 & -1.730330 & -0.846218 & -1.720510 & -0.362138 & 4 \\
Jashore & 40.05 & 2.506970 & 1.378980 & -0.651700 & -0.612183 & 6 \\
Munshigon & 32.41 & 0.127910 & -1.492190 & 0.849334 & 0.885200 & 3 \\
\hline
\end{tabular}

\section{AMMI Stability Value (ASV)}

In fact, ASV is the distance from zero in a two-dimensional scatter-gram of IPCA1 (principal interaction component analysis axis 1) scores against IPCA2 scores. Since the IPCA1 score contributes more to GE sum of scores, it has to be weighted by the 
proportional difference between IPCA1 and IPCA2 scores to compensate for the relative contribution of IPCA1 and IPCA2 total GE sum of squares. The distance from zero is then determined using the theorem of Pythagoras (Purchase et al., 2000).

In the ASV method, a genotype with least ASV score is the most stable; accordingly, genotype clone 9.125, followed by BARI Alu-28 (Lady Rosetta), and clones 9.91 wasthe most stable while 9.35 were undesirable. Biplot analysis and ordination techniques revealed significant differences between IPCA1 and IPCA2.

The first two principal interaction components (IPCA1 and IPCA2) explained $84.31 \%$ of the variability in the GE interaction. In general, the importance of AMMI model is in the reduction of the noise even if the principal component does not cover much of the GESS (Coe, 1996). Biplot analysis (Fig.1) displayed that clone 9.44 and 9.35 and the environment of Gazipur and Jashore (Table 11) had the greatest effect on the GE interaction. Clone 9.44 had specific adaptation with the environment of Gazipur and Jashore, while 9.35 had specific adaptation with the environment of Gazipur and Jamalpur. Genotypes toward the center of biplot have zero interaction; therefore, have general adaptation with different mean tuber yield. Clone 9.125, 9.91, BARI Alu-28 (Lady Rosetta), BARI Alu-8 (Cardinal) and clone 9.112 were located in this category; therefore, they can be considered as stable with high performance. Biplot of IPCA1 and IPCA2 (Fig. 1) covers $84.3 \%$ of GE interaction.

As AMM12 has the least RMSPD (root mean square predictive difference), therefore recommendation must be based on this model (Farshdfar and Sutka, 2006). In pattern analysis, genotypes are judged in grouping from and therefore save time and precision in interpretation and selection (Farshadfar and Sutka, 2003).

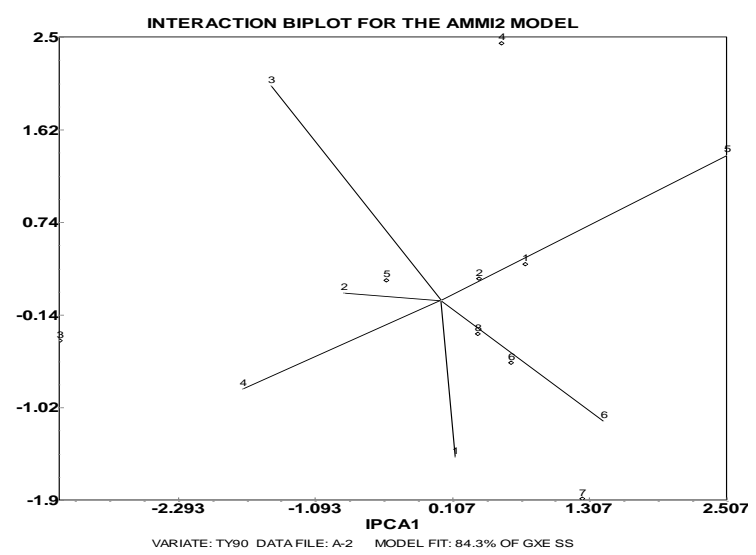

Figure 1. Biplot analysis of GE interaction based on AMMI2 model for the first two interaction principal component scores. The designations for the genotypes are: 1=9.112. $2=9.125,3=9.35,4=9.44,5=9.91,6=$ Cardinal, $7=$ Diamant and $8=$ Lady Rosetta. The environments are represented by $1=$ Bogura, $2=$ Debigon, $3=$ Gazipur, 4=Jamalpur, 5=Jashore and 6=Munshigon 


\section{Genotypic Selection Index (GSI)}

Stability should however, not be the only parameter for selection because the most stable genotypes would not necessarily give the best yield performance (Mohammadi et al., 2007).Hence there is a need for approaches that incorporate both mean grain yield and stability in a single criteria, that's why Kang $(1991$; 1993) introduced three selection criteria for simultaneous selection of yield and stability entitled: rank-sum (RSM), modified rank-sum (MRSM) and the statistics yield-stability $\left(\mathrm{Ys}_{\mathrm{i}}\right)$.

In this regard, as ASV takes into account both IPCA1 and IPCA2 that justifies most of the variation of GE interaction, therefore the rank of $\mathrm{ASV}_{\mathrm{i}}$; and mean grain yield $\left(\mathrm{R}_{\mathrm{ji}}\right)$ are incorporated in a single selection index namely Genotype Selection Index (GSI). The least GSI is considered as the most stable with high grain yield. Based on the GSI the most desirable genotype for selection of both stability and high grain yield is clone 9.125 followed by clone 9.112, 9.91 and 9.35, which are in agreement with the result of biplot. Even though they are more stable and higher yielder than checks.

\section{CONCLUSION}

Regarding tuber yield at 90DAP, clone 9.44 and 9.35, and the environment of Gazipur and Jashore had a great effect on the GE interaction. Clone 9.44 had specific adaptation with the environment of Gazipur and Jashore, while 9.35 had specific adaptation with the environment of Gazipur and Jamalpur. The most desirable genotype for selection of both stability and high tuber yield is in clone 9.125 followed by clone 9.112, 9.91and 9.35. These four can be evaluated in the regional yield trial for releasing as stable varieties.

\section{Conflict of interest}

The authors declare that there is no conflict of interest with this research.

\section{REFERENCES}

Asfaw, A., Alemayehu, F., Gurum, F. and Atnaf, M. (2009). AMMI and SREG GGE biplot analysis for matching varieties onto soybean production environments in Ethiopia, Scientific Research and Essays, 4(11): 1322-30.

Badoni, A. and Chauhan, J.S. (2010). Potato seed production of Cultivar Kufri Himalini, in vitro, Stem Cell, 1(1): 7-10.

BBS. (2019). Bangladesh Bureau of Statistics. Handbook of Agricultural Statistics. Pp 510. http://www.bbs.gov.bd/. Accessed 25 February, 2020.

Becker, H.C. and Leon, J. (1988). Stability Analysis in Plant Breeding, Plant Breeding, 101(1): 1-23.

Chandra, S., Sohoo, M.S. and Singh, K.P. (1971). Genotype x environment interaction for yield in gram, Punjab Agricultural University Journal Research, 8: 165-168. 
Coe, R. (1996). Statistical analysis of regional yield trials: AMMI analysis of factorial designs, Agricultural Systems, 51(2): 242-244.

Cornelius, P.L., Seyedsadr, M. and Crossa, J. (1992). Using the shifted multiplicative model to search for "separability" in crop cultivar trials, Theoretical and Applied Genetics, 84(1-2): 161-72.

Farshadfar, E. and Sutka, J. (2006). Biplot analysis of genotype-environment interaction in durum wheat using the AMMI model, Acta Agronomica Hungarica, 54(4): 459-467.

Farshadfar, E. and Sutka, J. (2003). Locating QTLs controlling adaptation in wheat using AMMI model, Cereal Research Communications, 31(3-4): 249-256.

Farshadfar, E. (2008). Incorporation of AMMI Stability Value and Grain Yield in a Single Non-Parametric Index (GSI) in Bread Wheat, Pakistan Journal of Biological Sciences, 11(14): 1791-1796.

Gauch, H.G. and Zobel, R.W. (1996). AMMI Analysis of Yield Trials. Genotype-byEnvironment Interaction. In: Kang MS, Gauch HG. eds. Genotype by environment interaction. CRC Press, Boca Raton, FL, USA, 85-122.

Kang, M.S. (1991). Modified rank-sum method for selecting high yielding, stable crop genotypes, Cereal Research Communications, 19: 361-364.

Kang, M.S. (1993). Simultaneous Selection for Yield and Stability in Crop Performance Trials: Consequences for Growers, Agronomy Journal, 85(3): 754-757.

Kundu, B.C., Hosssain, M.I., Rashid, M.H. and Naznin, S. (2018). Training Manual on Validation and Dissemination of Newly Released High Yielding and Climate Smart Potato Varieties. Tuber Crops Research Centre, Bangladesh Agricultural Research Institute, Joydebpur, Gazipur, Pp.2.

Mohammadi, R., Haghparast, R., Aghaee, M., Rostaee, M. and Pourdad, S.S. (2007). Biplot analysis of multi-environment trials for identification of winter wheat megaenvironments in Iran, World Journal of Agricultural Sciences, 3(4): 475-480.

Mohammadi, R. and Pourdad, S.S. (2008). Use of Stability Parameters for Comparing Safflower Genotypes in Multi-Environment Trials, Asian Journal of Plant Sciences, 7(1): 100-104.

Pourdad, S.S. and Mohammadi, R. (2008). Use of Stability Parameters for Comparing Safflower Genotypes in Multi-Environment Trials, Asian Journal of Plant Sciences, 7(1): 100-104.

Purchase, J.L., Hatting, H., and Van Deventer, C.S. (2000). Genotype $\times$ environment interaction of winter wheat (Triticum aestivum L.) in South Africa: II. Stability analysis of yield performance, South African Journal of Plant and Soil, 17(3): 101-107.

Rea, R., De Sousa-Vieira, O., Ramon, M., Alejos, G., Diaz, A. and Briceno, R. (2011). Ammi Analysis and its Application to Sugarcane Regional Trials in Venezuela, Sugar Technology, 13(2): 108-113.

Sadeghi, S.M., Samizadeh, H., Amiri, E. and Ashouri, M. (2011). Additive main effects and multiplicative interactions (AMMI) analysis of dry leaf yield in tobacco hybrids across environments, African Journal of Biotechnology, 10(21): 4358-4364. 
Singh, R.K. and Chaudhary, B.D. (1977). Biometrical methods in quantitative genetic analysis, Kalyani publishers, New Delhi, India.

Thillainathan, M. and Fernandez, G.C.J. (2002). A Novel Approach to Plant Genotypic Classification in Multi-site Evaluation, Horticulture Science, 37(5): 793-798.

Yan, W. and Hunt, L.A. (2001). Interpretation of Genotype $\times$ Environment Interaction for Winter Wheat Yield in Ontario, Crop Science, 41(1): 19-25.

Yau, S.K. and Hamblin, J. (1994). Relative Yield as a Measure of Entry Performance in Variable Environments, Crop Science, 34(3): 813-817.

Zobel, R.W., Wright, M.J. and Gauch, H.G. (1988). Statistical Analysis of a Yield Trial, Agronomy Journal, 80(3): 388-393. 